\title{
Effects of stocking density on dispersal behavior of Brazilian freshwater dourado (Salminus brasiliensis) in a subtropical river headwater
}

\author{
Uwe Horst Schulz and Mateus Evangelista Leal
}

Juvenile freshwater dourados (Salminus brasiliensis Cuvier) were stocked in two batches of different size (61 and 133 individuals) with a time lag of 41 days in the headwaters of the Sinos River. A subsample of 25 fish was radio-tagged. Released juveniles displayed a density dependent dispersal pattern. During the first ten days mean covered distance of tagged batch 1 individuals (low density) was approximately $24 \mathrm{~m} \mathrm{~d}^{-1}$, while batch 2 individuals (high density) moved $296 \mathrm{~m} \mathrm{~d}^{-1}$. Activity of batch 1 fish increased after the release of batch 2 and remained high $\left(459 \mathrm{~m} \mathrm{~d}^{-1}\right)$ until 90 days. Activity of batch 2 fish during this period was in same range. After this period, activity levels of both batches decreased to about $60 \mathrm{~m} \mathrm{~d}^{-1}$. Increased movements in higher density condition are seen as a result of interspecific competition. The mean covered distances per day remained high until stocked individuals become established in their new habitat.

Dois lotes de 61 e 133 dourados (Salminus brasiliensis Cuvier) juvenis foram introduzidos nas cabeceiras do rio dos Sinos. O intervalo entre as solturas foi de 41 dias. Uma subamostra de 25 peixes foi marcada com radiotransmissores. A dispersão dos indivíduos após soltura mostrou um padrão dependente da densidade. Durante os primeiros dez dias a distância média dos indivíduos do lote 1 (densidade baixa) foi de $24 \mathrm{~m} \mathrm{~d}^{-1}$, enquanto os indivíduos do lote 2 (densidade alta) percorreram em média $296 \mathrm{~m} \mathrm{~d}^{-1}$. A atividade dos peixes do lote 1 aumentou depois da soltura do lote 2 e permaneceu alta $\left(459 \mathrm{~m} \mathrm{~d}^{-1}\right)$ durante 90 dias. A atividade dos indivíduos do lote 2 ficou no mesmo nível durante este período. Depois os movimentos de ambos os lotes diminuíram até uma média de $60 \mathrm{~m} \mathrm{~d}^{-1}$. O nível alto de movimentos na situação de maior densidade é visto como resultado da competição intraespecífica. As médias das distâncias percorridas por dia permanecem altas até os indivíduos introduzidos estabelecerem-se nos seus habitats novos.

Key words: Density dependence, Dispersal, Intraspecific competition, Movements.

\section{Introduction}

Species richness of Brazilian freshwater ecosystems is among the highest in the world. Approximately 2600 freshwater fish species occur in Brazil (Buckup \& Menezes, 2003; Reis et al., 2003). However, in regions where the development of the local economy is not accompanied by protection or mitigation measures, the aquatic diversity is declining. The Brazilian red list of threatened species includes 134 fish species (Rosa \& Lima, 2008). The loss of aquatic diversity is caused by organic and industrial pollution, habitat degradation, dam construction, intensive fishing, and the introduction of alien species (Agostinho et al., 2005; Dudgeon et al., 2006; Júlio Júnior et al., 2009).

To mitigate the effects of environmental degradation, the stocking of fish in natural or semi-natural waterbodies like reservoirs is common practice in Brazil. In many cases stocking is performed with locally occurring species to enhance the stocks (Bizerril \& Primo, 2001; Vitule, 2009). Although restocking programs are under way worldwide, success stories are more exception than the rule (Molony et al., 2003). The cost benefit relation of many projects is on the costs side, because the costs for artificial reproduction and rearing in hatcheries surpass the economic revenue of the fishery based on the released fish (Ackefors et al., 1991; Patrick et al., 2006). Buynak \& Mitchell (1999) calculated a value of US\$ 66 for each Largemouth Bass (Micropterus salmoides) captured by anglers which originated from a 5-year stocking program. Additional concerns exist about the genetic impact of hatchery fish on wild populations. Inbreeding and outbreeding effects may occur, if broodstocks for artificial reproduction are not properly selected (Agostinho et al., 2010). In general, genetic diversity in hatchery fish usually is lower than in wild fish, contributing to a decrease of fitness of the introduced fish (Araki \& Schmidt, 2010).

Universidade do Vale do Rio dos Sinos (UNISINOS), Centro de Ciências da Saúde, Laboratório de Ecologia de Peixes, Av. Unisinos, 950, Bairro Cristo Rei, 93022-000 São Leopoldo, RS, Brazil. uwe@unisinos.br 
However, well designed stocking programs may enhance existing stocks and contribute to the preservation of dwindling populations (Hayes et al., 2004; Araki \& Schmidt, 2010). The almost extinct migrating brown trout (Salmo trutta $\mathrm{f}$. lacustris) populations of Lake Constance recovered after an integrated effort of Swiss, Austrian, and German stakeholders to redesign and improve an already existing stocking program of low success (Ruhlé et al., 2005). Yet, Brazil did not develop basic policies for stocking. Environmental risk analysis and assessments of environmental carrying capacities usually do not precede stocking programs (Agostinho et al., 2005). In Brazilian waters limited success of restocking programs is attributed to wrong selection of species, too high stocking densities, inadequate age or size of stocked fish and impropriate stocking habitats and periods (Agostinho et al., 2010). In many cases virtually no released fish is recaptured (Agostinho et al., 2004).

Stocking density may be a chronic stressor of fish behavior (Nieuwegiessen et al., 2008). Studies with different stocking densities use growth, mortality and movement as variables that may reflect competition (Fréchettea et al., 2005). Released fish may be submitted to intra- and interspecific competition, because of limited resources like food and habitat. Usually wild resident fish tend to win conflicts against stocked intruders (Huntingford \& DeLeaniz, 1997; Rhodes \& Quinn, 1998; Johnsson et al., 1999). The result may be a high dispersal or mortality rate of the released individuals.

The dourado Salminus brasiliensis (Cuvier) is a top predator in Brazilian freshwaters. The species may migrate several hundred kilometers during spawning migration in large rivers (Agostinho et al., 2003; Resende, 2003; Zaniboni-Filho $\&$ Schulz, 2003). In the relatively small Sinos River, south Brazil, spawning migrations extend up to $100 \mathrm{~km}$. The most important spawning sites are located in the river main stem below the headwater - floodplain transition (Schulz \& Costa, 2004), but, historically, the dourado occurred also in the Sinos headwaters. Interviews with residents of the area confirm that the high water transparency made the dourado an easy target for cast net fishers, who eliminated the population in this river reach about 30 years ago. The effects of dam construction, pollution and intense fishing activities put the species in the Red Book of Endangered Species of Rio Grande do Sul State (Fontana et al., 2003). The Sinos River is among the eight most polluted rivers of Brazil (ANA, 2009). At the moment only one out of 32 municipalities of the river basin operates sewage treatment plants. Water quality is class four, which is the worst of the Brazilian ranking system (CONAMA, 2005). In contrast to the lower parts of the basin, the headwaters still are in good conditions.

The critical environmental situation of the Sinos River and the declining dourado stocks, its condition as a flagship species in environmental education programs (COMITESINOS, 2011) and the favorable environmental conditions in the headwaters made the dourado a candidate for a restocking project. The objectives of this study were to re-introduce the dourado in Sinos River headwaters, to describe post-stocking movements and to investigate the influence of stocking density on dispersal and habitat choice of released individuals.

\section{Material and Methods}

\section{Study area}

The Sinos River basin is located in the northeastern part of Rio Grande do Sul State, Brazil. It covers a total area of about $4000 \mathrm{~km}^{2}$. The rivers length is $190 \mathrm{~km}$, and extends from the slopes of the Serra Geral to the Guaíba Lake (Fig. 1). The climate is subtropical with mean annual rainfalls of $1350 \mathrm{~mm}$ (FEPAM, 2010).

The headwaters, located at a distance of 183 kilometers from the river mouth, were selected for the stocking experiment. A small resident dourado population still occurs in a large pool of $1 \mathrm{~km}$ extension at the headwater lowland transition at a distance of $28 \mathrm{~km}$ downstream from the stocking area.

The stocked river stretch is a high gradient water course with $8 \mathrm{~m} \mathrm{~km}^{-1}$ declivity. Mean discharge was calculated to be $2 \mathrm{~m}^{3} \mathrm{~s}^{-1}$, river width varied between 6 and $15 \mathrm{~m}$. It is segmented by a headwater typical pool-riffle sequence with some rapids and glides. Pool depths vary between one and five meters. Riparian vegetation is still in good conditions with buffer strips extending $30 \mathrm{~m}$ on both sides of the river bank. Water transparency is high with Secchi depths of up to four meters.

\section{Stocking}

The study extended from January to June 2009. Three pools of a mean surface of $1200 \mathrm{~m}^{2}$ and a depth between one and four meter were selected in a river stretch of $250 \mathrm{~m}$.

A total of 194 individuals divided in two batches of 61 and 133 individuals were released. All individuals were marked by removing the adipose fin (Schulz, 1997) in order to identify the individuals as stocked fish in future captures. The first batch was stocked on January $27^{\text {th }}$. The 61 individuals of the first batch correspond to a density of

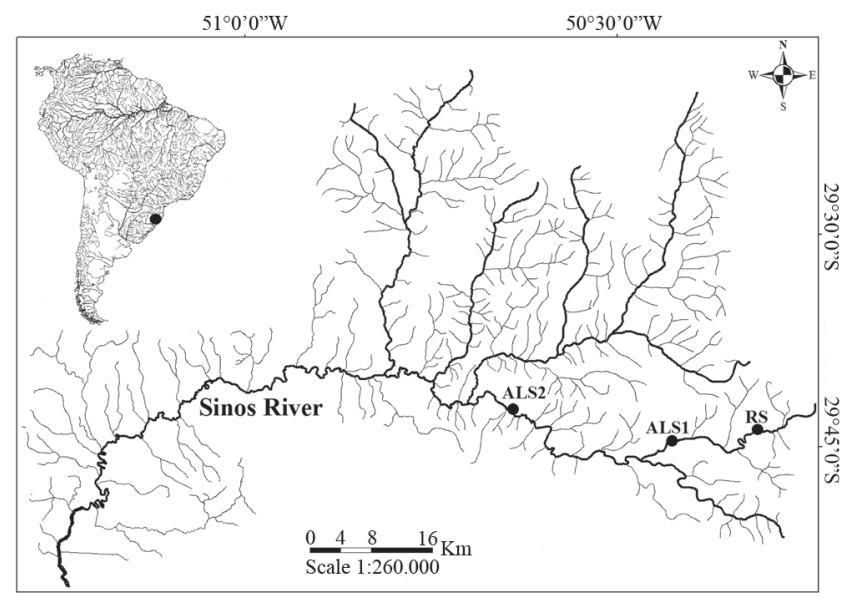

Fig. 1. Sinos River basin. ALS=Automatic Listening Station, $\mathrm{RS}=$ Release Site. 
0.017 fish $\mathrm{m}^{-2}$ in each stocking pool. Since the carrying capacity of the Sinos River was unknown, stocking density was based on recommendations for salmon smolts which are stocked at approximately the same body size (Aprahamian et al., 2003). A subsample of 13 individuals was tagged with digitally coded radio transmitters (Lotek NanoTags NTC-42L, 87 days battery life, $2.6 \mathrm{~g}$ weight in air; transmitter-bodyweight relation $<3 \%$ ) using the standard surgical procedure described by Schulz \& Leuchtenberger (2006).

The second batch of 133 individuals was released in the same pools on March $10^{\text {th }}$. Twelve fish were tagged with radio transmitters. The initial stocking density was more as twice as high and corresponded to 0.04 fish $\mathrm{m}^{-2}$, not counting the fish of batch 1. Mean length $(20.4 \mathrm{~cm}$, standard error s.e. 0.4$)$ of the individuals of batch 1 did not differ significantly from mean length $(19.8 \mathrm{~cm}$, s.e. 0.26$)$ of the individuals of batch 2 (Mann-Whitney U-Test $=4277, \mathrm{p}=0.376$ ). The stocked fish were produced by a local fish farm using a Sinos River broodstock in November 2008.

Radio tagged fish were tracked twice a week between $27^{\text {th }}$ of January and $30^{\text {th }}$ of May 2009. Standard procedure was mobile tracking by car using a Lotek SX400A-W5XS receiver with a portable two-element yagi antenna. When a signal was detected, the spot localization and the identification of the individual code occurred on foot. Water depth was measured with a graded rod and attributed to depth categories of $<1 \mathrm{~m}$, $1 \mathrm{~m}-2 \mathrm{~m},>2 \mathrm{~m}$. When fish could be visualized during tracking, additional observations of their behavior (like shoaling) were registered.

The surveyed river stretch had an extension of $70 \mathrm{~km}, 63$ $\mathrm{km}$ downriver and seven $\mathrm{km}$ upriver of the release site. This distance was covered between 09.00 hours and 18.00 hours on each tracking day, always moving upriver beginning at the automatic listening station 2 (Fig. 1). Geographical coordinates were registered by an Etrex Vista HCX GPS with a precision of approximately $10 \mathrm{~m}$ and transferred to digital map based on the 1:50.000 scale maps of the Brazilian Ministry of Defense. All position fixes were transformed into distances from river mouth. Consequently, the difference between two subsequent measures corresponds to the distance covered during this interval.

Additionally, tagged fish were tracked by aircraft two times per month to locate individuals which dispersed from the headwaters to the floodplain. The aircraft survey covered the entire river extension from the river mouth to the headwaters. Previous tests showed that the accuracy of aerial tracking was about $200 \mathrm{~m}$ (Pesoa \& Schulz, 2010).

Additionally to the mobile tracking, two automatic listening stations (ALS; Lotek SX400A-W7) were deployed downriver of the investigation area. Both ALS were equipped with four element yagi antennas. ALS1 was installed $28 \mathrm{~km}$ downriver of the release site at the transition between headwaters and floodplain. ALS2 was deployed in the floodplain, $63 \mathrm{~km}$ downriver of the release site. Individuals which passed ALS2 were considered to have left the study area. Data of ALS were downloaded in weekly intervals.

\section{Data processing}

Dispersal of the individuals of both batches was determined as the mean distance covered by each radiotagged fish per day. It was calculated by dividing the distance of subsequent position fixes by the number of days which passed between the fixes. Mean covered distances of both batches during the first ten days were compared by ANOVA. The data were $\log (x+1)$ transformed to meet normality and homoscedasticity citeria. Standard error was used as dispersion measure. Considering that the first introduced batch would reduce food resources in the stocking area, the second batch was expected to disperse longer distances, particularly during the first period after release. In an additional comparison, mean covered distances per day of both batches were plotted in two week intervals, covering the complete investigation period of 120 days.

The total ranges of radio tagged fish were defined as distances between the most upstream and downstream locations during the tracking period. Individual ranges of batch 1 and batch 2 dourados were compared by MannWhitney U-Test (SPSS Statistics vers. 17).

\section{Results}

Batch 1 and batch 2 fish produced 359 position fixes. Batch 1 dourados were recorded 243 times and the individuals of the second batch 116 times. Not all tagged fish could be located on each tracking day. On several occasions tagged and untagged fish were observed moving together.

One fish out of 25 was lost and never located (batch 2). Of the 24 evaluated fish, a total of 21 individuals (87.5\%) remained in the study area. Three individuals (12.5\%) dispersed far downstream. The first two of these fishes belonged to batch 1 . They were registered by ALS1 65 days and by ALS2 71 days after release. After 86 days both fish were recorded by aircraft at $80 \mathrm{~km}$ distance from the release site. The third fish belonging to batch 2 was registered by ALS1 22 days and by ALS2 32 days after release. After 61 days this individual was recorded the last time at $72 \mathrm{~km}$ from the release site (Fig. 2). None of these long dispersed individuals was detected during later aircraft tracking between river mouth and study area.

After released, dourados of batch 1 remained in the stocking pools for a period of up to 20 days. The dispersal was gradual, no synchronized movements were observed. Five radio tagged individuals moved upstream, eight downstream (Fig. 2). When batch 2 was released, no tagged individual of batch 1 was still present in the release pools. The first fish left the pool on the first day after stocking, the last one after 10 days. Of all radio tagged individuals of the second batch three moved upstream and eight downstream. The extended sojourn of batch 1 dourados in the release pools and the rapid exit of batch 2 fish caused significant differences in mean daily covered distances during the first ten days after stocking, which increased ten fold in batch 2 fish $\left(\mathrm{F}_{(55)}=\right.$ $7.582, \mathrm{p}=0.008)($ Fig. 3). 


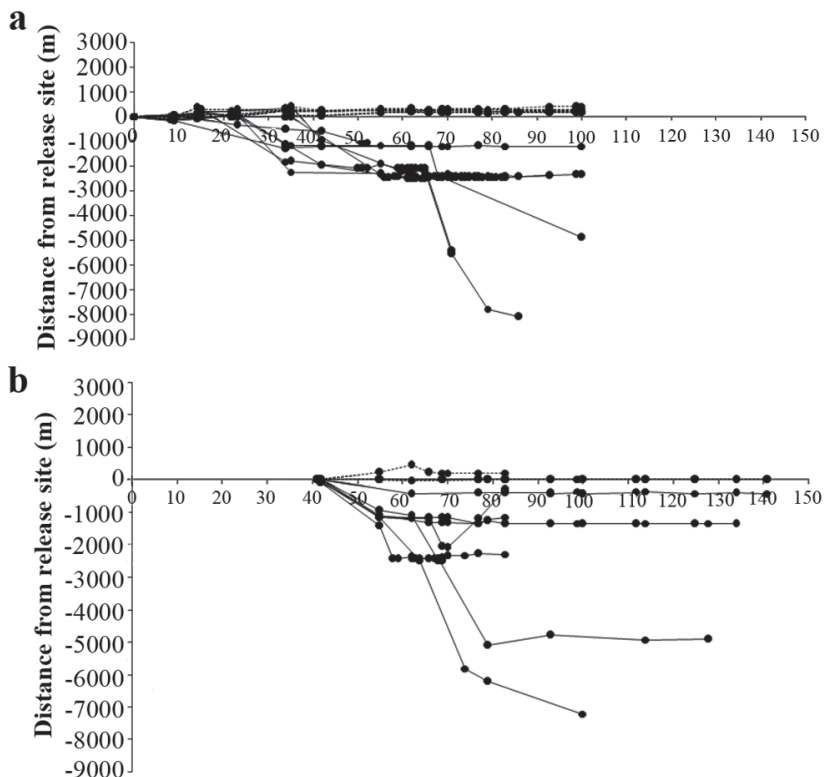

Fig. 2. Distances covered by batch 1 (a) and batch 2 (b) dourados. Release point $=$ Stream position 0 . Positive values $=$ upstream movement (hatched lines); negative values $=$ downstream movement (solid lines).

Tagged fish from batch 1 and batch 2 remained separated during the study. The horizontal separation of both batches was defined by the limits of the riffle-pool-segment. Batch 1 and batch 2 fish did not occur in the same segment. Only one individual of batch 2 joined fish of batch 1 and stayed with them until the battery of the transmitter expired.

The Fig. 4 displays temporal dispersal patterns of both batches. When the first fish from batch 1 left the release pools, the mean covered distance increased to $200 \mathrm{~m}$ and remained almost constant during the first month. When batch 2 was introduced, mean covered distance of batch 1 increased to 459 $\mathrm{m} \mathrm{d}^{-1}( \pm 144.8)$ and remained high until 90 days. During the last 15 days interval the mean covered distance decreased to 57.4 $\mathrm{m} \mathrm{d}^{-1}( \pm 15.1)$. When batch 2 fish were released, their daily initial dispersal rates varied between $343.4 \mathrm{~m} \mathrm{~d}^{-1}( \pm 118.2)$ and $448.5 \mathrm{~m} \mathrm{~d}^{-1}( \pm 138.6)$ during the first 45 days, then decreased to $75.9 \mathrm{~m} \mathrm{~d}^{-1}( \pm 33.3), 27 \mathrm{~m} \mathrm{~d}^{-1}( \pm 14)$ and $14.6 \mathrm{~m} \mathrm{~d}^{-1}( \pm 7.2)$.

The median range of batch $1(13,031 \mathrm{~m})$ and batch $2(13,769$ m) fish did not differ significantly (Mann-Whitney U-Test $=69$, $p=0.664)$. When median ranges were tested for fish in upstream $(2,602 \mathrm{~m})$ and downstream $(22,641.5 \mathrm{~m})$ direction, differences were significant (Mann-Whitney U-Test $=12.0, p=0.005$ ) showing that most of the movements were directed downstream. Upriver movements passed artificial and natural barriers of about two meters height and shallow rapids (10 cm deep).

During the study, released fish adapted their body color to the environment and their behavior became more inconspicuous. The visual location of tagged individuals was frequent during the first two months. After this initial period visual contact was rare.

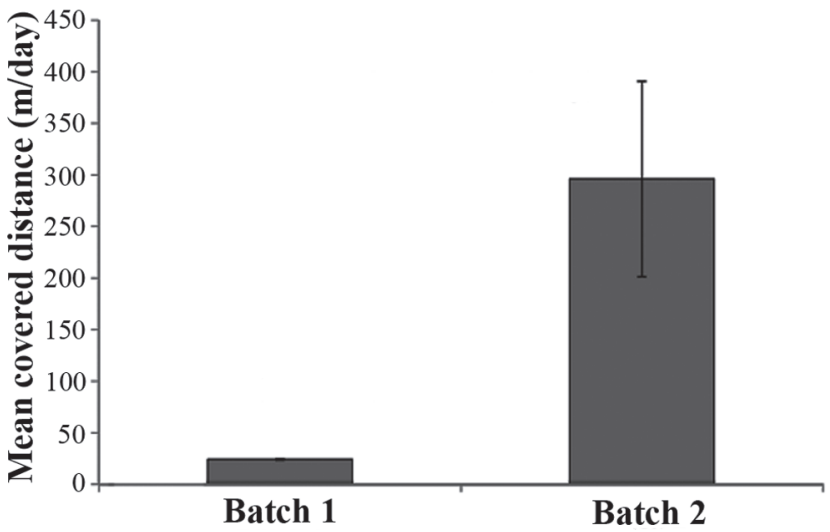

Fig. 3. Mean covered distance per day of batch $1(\mathrm{n}=27 ; \bar{x}=$ $24.30 \mathrm{~m} \pm 0.65)$ and batch $2(\mathrm{n}=29 ;=296.34 \mathrm{~m} \pm 94.73)$ during the first ten days after release.

Batch 1 fish showed a preference for pools with depths of more than $2 \mathrm{~m}\left(\mathrm{X}^{2}=10.432, \mathrm{p}=0.021\right)$ while batch 2 fish were encountered in all depth ranges $\left(X^{2}=3.596, p=0.102\right)$. When fish could be sighted during tracking, they occurred in small shoals of three to maximum eight individuals. Shoals were composed of tagged and untagged individuals swimming in coordinated movements. Mean group size of batch 1 sightings (3.7 individuals \pm 0.35 ) did not differ significantly from mean group size of batch 2 sightings (3.8 individuals \pm 0.8 ) (MannWhitney U Test $=1986.50, \mathrm{p}=0.06$ ).

\section{Discussion}

The transport, tagging surgery and the release operation did not cause observable effects on the stocked fish. All tagged individuals moved after release, and no fish were found dead during the experiment. Only one batch 2 individual left the release pool the first day after stocking and was never recorded. Another three individuals produced only three records. They may have left the study area without being recorded by the ALS, may have been captured by illegal fishing or otter predation. Otter spraints were frequently found in the investigation area. Radio tagging most certainly did not affect the behavior. On several occasions tagged and untagged individuals were observed moving in coordinated movements.

High densities may affect stocked fish particularly in three aspects: movement rates of stocked fish may increase as a consequence of avoidance behavior to limit intraspecific competition; increased density may reduce the availability of food resources and cause growth reduction; mortality rates may increase due to severe intraspecific competition for food and space resources. These effects may act on different time scales, where increased movement rates are supposed to occur shortly after stocking and mortality being a long term effect. Since the present study covered a restricted time interval of approximately 90 days due to the short life of the small radio transmitters, the results are limited to short term effects. 


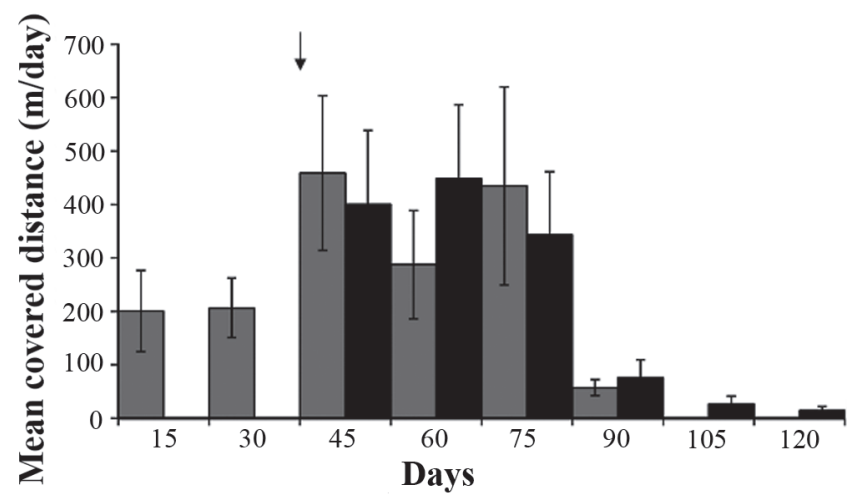

Fig. 4. Mean covered distance by day during 15 days periods of batch 1 (grey bars) and batch 2 (black bars). The vertical arrow indicates the release of batch 2 .

The differences in mean dispersal distances of batch 1 and batch 2 most probably reflect the effects of intraspecific competition. When batch 1 individuals were released into the stocking pools, fish stayed there for up to 20 days. During their dispersal into the adjacent river stretches, daily activity was relatively low $\left(200 \mathrm{~m} \mathrm{~d}^{-1}\right)$. When batch 2 was stocked, it is likely that food resources of the release pools were already depleted. Therefore, food scarcity might be the driving factor for short sojourn of maximum 10 days of batch 2 fish. When batch 2 fish dispersed from the release pools, they encountered batch 1 fish occupying the most suitable habitats of higher water depth. During this phase the density of juvenile dourados in the study area increased threefold (batch $1=61$; batch $2=$ 133). Activity of batch 1 fish doubled from $200 \mathrm{~m} \mathrm{~d}^{-1}$ to $459 \mathrm{~m} \mathrm{~d}^{-}$ ${ }^{1}$ and remained high during the next 45 days. Activity of batch 2 fish was also high during the same period.

Increased initial dispersal rates occur when fish explore a new environment until they become established in a suitable habitat. Most stocked fish stay near the release area but few fish may travel a long distance shortly after release (Templeton, 1970; Hudy \& Shiflet, 2009), as did three individuals of this study. Stocking habitat, flow conditions and time of release are variables that influence post stocking movements. Usually, already established (wild) individuals disperse less than released individuals (Popoff \& Neumann, 2005; Bolland et al., 2009; Turek et al., 2010) although there are exceptions (Joergensen \& Berg, 1991). In the present study, already established batch 1 dourados increased their daily movement rates when batch 2 was introduced, but both batches remained horizontally separated: batch 1 occurring in riffle-pool sequences with deeper pools. This situation may be caused by a partial prior residence effect. Huntingford \& de Leaniz (1997) and Rhodes \& Quinn (1998) found that salmonids first introduced into artificial or natural systems establish territories and defend them more successfully than later introduced conspecifics. The exact mechanism of spatial segregation in juvenile dourados remains unexplained because behavioral interaction is not driven by the establishment of individual territories. Since dourados were frequently observed hunting in groups, occupying an entire riffle-pool segment, the shoal might expel intruders actively from the segment, or incoming individuals or shoals avoid the already established fish.

The shoaling behavior may be an efficient feeding strategy. Several fish species predate more successfully when shoaling in small groups (Parrish, 1993). Juvenile Australian salmon (Arripis trutta) achieved higher rates of successful attacks on mysids (Paramesopodopsis rufa) by forming shoals of six fish, reducing the confusion effect of the swarming prey (Foster et al., 2001). Since the most abundant prey in the headwaters are small shoaling Characids of the genus Astyanax and Bryconamericus, group hunting may increase feeding efficiency.

Tagging studies with adult dourados in the lower Sinos River suggest that individuals which attained maturity stay permanently in the Sinos and do not stray into other basins (Burns, 2004). If adult fish do not disperse out of the river basin, gene flow between adjacent river systems should be maintained by out moving juveniles. The three fish which dispersed out of the study area into the lower river sections may represent this part of the population. Most probably they left the Sinos River, considering that they were not detected by aircraft tracking, which covered the entire river extension.

The predominant dispersal direction of the dourados was downstream, only one third moved upstream. Most studies observe predominant downstream movements after stocking (Cresswell, 1981), although there are many exceptions. Einum $\&$ Nislow (2005) found in a two year study that salmon $(S$. salar) fry from introduced redds dispersed more upstream during the first year and downstream during the second. During the second year a heavy spate stroke the study sites and, most probably, juveniles were dislocated passively. Observations of Popoff \& Neumann (2005) show similar results. Stocked trout (S. trutta) of hatchery origin moved downstream in a year with high discharge and upstream during low discharge conditions. These results show that up- or downstream dispersal depends on annual oscillations of the flow regime.

Salmonids in streams of comparable size usually disperse less than dourados. Brown trout released into a stream in Connecticut, USA dispersed a mean distance of $500 \mathrm{~m}$ within 2 weeks and $930 \mathrm{~m}$ within 12 weeks. The maximum dispersal distance was $4.11 \mathrm{~km}$ (Popoff \& Neumann, 2005). Most publications indicate that about $90 \%$ of released adult brown trout (S. trutta) disperse less than $4.5 \mathrm{~km}$ (Cresswell, 1981). Factors that influence dispersal and survival of salmonids are the season of the stocking, autumn releases being less effective, size of the receiving river, smaller streams inducing higher downstream dispersal rates, and water temperature, observing that trout released in cold water displayed a higher tendency to move than fish stocked in warmer water. The median dispersal range of dourados was approximately $13 \mathrm{~km}$ in 90 days. Probably the feeding strategy of juvenile dourados contributes to major dispersal because they do not establish feeding territories but hunt their food in larger extensions of the river. 
The present study has led to encouraging results. On the short term, the stocking of dourados in the Sinos River headwaters was successful. The majority of the introduced individuals dispersed as intended in the available habitats and survival was high. Most probably low stocking density did not surpass the carrying capacity of the system and most of stocked individuals stayed in the study area during the investigation period. However, even on the short term, higher density increased dispersal and drove later released fish to less favorable habitats. Additional studies should investigate the long term behavior of the released fish, particularly if they succeed to reproduce.

\section{Acknowledgements}

The study was funded by Petrobras Ambiental. Graduate participants received Unisinos, CNPq and FAPERGS scholarships. FEPAM provided the license for stocking (No. 306/2008-DL). The editor and two unknown referees improved a former version of the manuscript substantially by their comments. We wish to thank them all.

\section{Literature Cited}

Ackefors, H., N. Johansson \& B. Wahlberg. 1991. The Swedish compensatory programme for salmon in the Baltic: an action plan with biological and economic implications. ICES Marine Science Symposia, 192: 109-119.

Agostinho, A. A., L. C. Gomes \& J. D. Latini. 2004. Fisheries management in Brazilian reservoirs: lessons from/for South America. Interciência, 29: 334-338.

Agostinho, A. A., L. C. Gomes, H. I. Suzuki \& H. F. Júlio-Jr. 2003. Migratory fishes of the Upper Rio Paraná Basin, Brazil. Pp. 19-98. In: Carolsfeld, J., B. Harvey, C. Ross \& A. Baer (Eds.). Migratory fishes of South America: biology, fisheries, and conservation status. Victoria, Canada: World Fisheries Trust/ IDRC/World Bank, 372p.

Agostinho, A. A., F. M. Pelicice, L. C. Gomes \& H. Ferreira Júlio Jr. 2010. Reservoir fish stocking: When one plus one may be less than two. Natureza \& Conservação, 8: 103-111.

Agostinho, A. A., S. M. Thomaz \& L. C. Gomes. 2005. Conservation of the Biodiversity of Brazil's Inland Waters. Conservation Biology, 19: 646-652.

ANA. 2009. Relatório de Conjuntura dos Recursos Hídricos no Brasil. Agência Nacional das Águas. Avaliable from: htpp:// www.ana.gov.br [accessed 05 June 2009].

Aprahamian, M. W., K. M. Smith, P. McGinnity, S. McKelvey \& J. Taylor. 2003. Restocking of salmonids - opportunities and limitations. Fisheries Research, 62: 211-227.

Araki, H. \& C. Schmidt. 2010. Is hatchery stocking a help or harm? Evidence, limitations and future directions in ecological and genetic surveys. Aquaculture, 308: 2-11.

Bizerril, C. R. S. F. \& P. B. S. Primo. 2001. Peixes de águas interiores do Estado do Rio de Janeiro. Rio de Janeiro, PLANAGUAFEMAR/SEMADS, $417 \mathrm{p}$.

Bolland, J. D., I. G. Cowx \& M. C. Lucas. 2009. Dispersal and survival of stocked cyprinids in a small English river: comparison with wild fishes using a multi-method approach. Journal of Fish Biology, 74: 2313-2328.
Buckup, P. A., N. A. Menezes \& M. S. Ghazzi. 2007. Catálogo das espécies de peixes de água doce do Brasil. Rio de Janeiro, Museu Nacional, 195p.

Burns, M. D. M. 2004. Migração e uso de habitat do dourado, Salminus brasiliensis, no Rio dos Sinos, Rio Grande do Sul, Brasil. Unpublished MSc. Dissertation, Universidade do Vale do Rio dos Sinos, São Leopoldo, 40p.

Buynak, G. L. \& B. Mitchell. 1999. Contribution of stocked advanced-fingerling largemouth bass to the population and fishery at Taylorsville Lake, Kentucky. North American Journal of Fisheries Management, 19: 494-503.

COMITESINOS. 2011. Projeto Dourado. Comitê de Gerenciamento da Bacia do Rio dos Sinos. Avaliable from: http: \www.comitesinos.com.br [accessed 20 April 2011].

CONAMA. 2005. Resolução $\mathrm{n}^{\circ} 357$ de 17 de março de 2005. Conselho Nacional do Meio Ambiente. Avaliable from: htpp:/ /www.mma.gov.br/conama/ [acessed 15 March 2011].

Cresswell, R. C.1981. Post-stocking movements and recaptures of hatchery-reared trout released into flowing waters - a review. Journal of Fish Biology, 18: 429-442.

Dudgeon, D., A. H. Arthington, M. O. Gessner, Z. I. Kawabata, D. J. Knowler, C. Leveque, R. J. Naiman, A. H. Prieur-Richard, D. Soto, M. L. J. Stiassny \& C. A. Sullivan. 2006. Freshwater biodiversity: importance, threats, status and conservation challenges. Biological Review, 81: 163-182.

Einum, S. \& K. H. Nislow. 2005. Local-scale density-dependent survival of mobile organisms in continuous habitats: an experimental test using Atlantic salmon. Oecologia, 143: 203-210.

FEPAM. 2010. Qualidade das águas na bacia hidrográfica do Rio dos Sinos. Fundação Estadual de Proteção Ambiental Henrique Luiz Roessler. Avaliable from: http://www.fepam.rs.gov.br/ qualidade/qualidade_sinos/sinos.asp [accessed 18 March 2010].

Fontana, C. S., G. A. Bencke \& R. E. Reis. 2003. Livro vermelho da fauna ameaçada de extinção no Rio Grande do Sul. Porto Alegre, Edipucrs, 632p.

Foster, E. G., D. A. Ritz, J. E. Osborn \& K. M. Swadling. 2001. Schooling affects the feeding success of Australian salmon (Arripis trutta) when preying on mysid swarms (Paramesopodopsis rufa). Journal of Experimental Marine Biology and Ecology, 261: 93-106.

Fréchettea, M. T., M. Alunno-Brusciab, R. S. Dumaisc \& G. Daiglee. 2005. Incompleteness and statistical uncertainty in competition/ stocking experiments. Aquaculture, 246: 209-225.

Hayes, S. A., M. H. Bond, C.V. Hanson \& R. B. MacFarlane. 2004. Interactions between endangered wild and hatchery salmonids: can pitfalls of artificial propagation be avoided in small coastal streams? Journal of Fish Biology, 65: 101-121.

Hudy, M. \& J. Shiflet. 2009. Movement and Recolonization of Potomac Sculpin in a Virginia Stream. North American Journal of Fisheries Management, 29: 196-204.

Huntingford, F. A. \& C. G. De Leaniz. 1997. Social dominance, prior residence and acquisition of profitable feeding sites in juvenile Atlantic salmon. Journal of Fish Biology, 54: 469-472.

Joergensen, J. \& S. Berg. 1991. Stocking experiments with 0+ and 1+ trout parr, Salmo trutta L., of wild and hatchery origin: 2. Poststocking movements. Journal of Fish Biology, 39: 171-180.

Johnsson, S., F. Nöbbelin \& T. Bohlin. 1999. Stocking of brown trout Salmo trutta L.: effects of acclimatization. Fisheries Management and Ecology, 6: 459-473.

Júlio Júnior, H. F., C. Dei Tos, A. A. Agostinho \& C. S. Pavanelli. 2009. A massive invasion of fish species after eliminating a 
natural barrier in the upper rio Paraná basin. Neotropical Ichthyology , 7: 709-718.

Molony, B. W., R. Lenanton, G. Jackson \& J. Norris. 2003. Stock enhancement as fisheries management tool. Reviews in Fish Biology and Fisheries, 13: 409-432.

Nieuwegiessen, P. G. van de, A. S. Boerlage, J. A. J. Verreth \& J. W. Schrama. 2008. Assessing the effects of a chronic stressor, stocking density, on welfare indicators of juvenile African catfish, Clarias gariepinus Burchell. Applied Animal Behaviour Science, 115: 233-243.

Parrish, J. K. 1993. Comparison of the hunting behavior of four piscine predators attacking schooling prey. Ethology, 95: 233-246.

Patrick, W. S., O. Bind, K. A. Schwabec \& P. W. Schuhmann. 2006. Hatchery programs, stock enhancement, and cost effectiveness: A case study of the Albemarle Sound/Roanoke River stocking program 1981 -1996. Marine Policy, 30: 299-307.

Pesoa, N. A. \& U. H. Schulz. 2010. Diel and seasonal movements of grumatã (Prochilodus lineatus, Valenciennes 1836) (Characiformes: Prochilodontidae) in the Sinos River, Southern Brazil. Brazilian Journal of Biology, Suppl., 70: 1169-1177.

Popoff, N. D. \& R. M. Neumann. 2005. Range and movement of resident holdover and hatchery brown trout tagged with radio transmitters in the Farmington river, Connecticut. North American Journal of Fisheries Management, 25: 413-422.

Reis, R. E., S. O. Kullander \& C. J. Ferraris-Jr. 2003. Check list of the freshwater fishes of South and Central America. Porto Alegre, Edipucrs, 729p.

Resende, E. K. 2003. Migratory fishes of the Paraguay-Paraná Basin, excluding the Upper Paraná Basin.Pp.99-155. In: Carolsfeld, J., B. Harvey, C. Ross \& A. Baer (Eds.). Migratory fishes of South America: biology, fisheries, and conservation status. Victoria, Canada: World Fisheries Trust/IDRC/World Bank, 372p.

Rhodes, J. S. \& T. P. Quinn. 1998. Factors affecting the outcome of territorial contest between hatchery and naturally reared coho salmon parr in the laboratory. Journal of Fish Biology, 53: $1220-1230$.
Rosa, R. S. \& F. C. T. Lima. 2008. Os Peixes Brasileiros Ameaçados de Extinção. Pp. 8-286. In: Monteiro, A. B. M, G. M. Drummond \& A. P. Paglia (Eds.) Livro vermelho da fauna brasileira ameaçada de extinção. Brasília, DF : MMA; Belo Horizonte, MG : Fundação Biodiversitas, 2: 1420p.

Ruhlé, C., G. Ackermann, R. Berg, T. Kindle, R. Kistler, M. Klein, M. Konrad, H. Löffler, M. Michel \& B. Wagner. 2005. Die Seeforelle im Bodensee und seinen Zuflüssen: Biologie und Management. Österreichs Fischerei, 58: 230-262.

Schulz, U. H. 1997. Mark retention in fin-clipped pacú, Piaractus mesopotamicus (Holberg, 1887) and short review of batchmarking techniques. Revista Unimar, 19: 413-419.

Schulz, U. H. \& P. F. Costa. 2004. Projeto Peixe Dourado. Pp.1928. In: Martins, I. T., H. C. Prieto \& U. H. Schulz (Eds.). Vida: Uma abordagem ambientalista. Porto Alegre: Ediplast, 102p.

Schulz, U. H. \& C. Leuchtenberger. 2006. Activity patterns of South American silver catfish (Rhamdia quelen). Brazilian Journal of Biology, 66: 565-574.

Templeton, R.G. 1970. Movement of hatchery reared brown trout introduced into the River Ure at Ripon, Yorkshire. Fisheries Management, 1: 35-43.

Turek, J., T. Randak., P. Horky, V. Zlabek, J. Velisek, O. Slavik \& R. Hanak. 2010. Post-release growth and dispersal of pond and hatchery-reared European grayling Thymallus thymallus compared with their wild conspecifics in a small stream. Journal of Fish Biology, 76: 684-693.

Vitule, J. R. S. 2009. Introdução de peixes em ecossistemas continentais brasileiros: revisão, comentários e sugestões de ações contra o inimigo quase invisível. Neotropical Biology and Conservation, 4: 111-122.

Zaniboni-Filho, F. E. \& U. H. Schulz. 2003. Migratory fishes of the Uruguay River. Pp. 157-194. In: Carolsfeld, J., B. Harvey, C. Ross \& A. Baer (Eds.) Migratory fishes of South America: biology, fisheries, and conservation status. Victoria, Canada: World Fisheries Trust/IDRC/World Bank, 372p.

Submitted June 20, 2011

Accepted April 3, 2012

Published June 29, 2012 